\title{
Effects of starvation and refeeding on growth performance and stress defense mechanisms of stellate sturgeon Acipenser stellatus juveniles from aquaculture*
}

\author{
Iulia Elena Florescu (Gune)' ${ }^{1}$ Alexandru Burcea1', Gina Oana Popa', Andreea Dudu1',

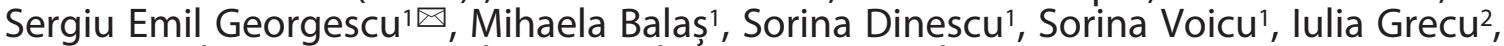 \\ Lorena Dediu' ${ }^{2}$, Anca Dinischiotu ${ }^{1}$ and Marieta Costache ${ }^{1}$
}

1Department of Biochemistry and Molecular Biology, University of Bucharest, Faculty of Biology, Bucharest, Romania; ${ }^{2}$ Department of Aquaculture, Environmental Sciences and Cadastre, "Lower Danube" University of Galați, Faculty of Environmental Science and Biotechnology, Galati, Romania

Acipenser stellatus represents a species of great economical interest due to its roe used for caviar production. Therefore, it has been intensively captured for decades and nowadays, this species is on the verge of extinction. As a consequence, Acipenser stellatus is intensively raised in fish farms. Aquaculture is focused on optimizing the feeding regime of juveniles. The aim of this study was to investigate if Acipenser stellatus can adapt to a starvation/refeeding regime by assessing the effects of this regime on growth performance, oxidative stress biomarkers and heat shock protein ( $h s p$ ) gene expression in juveniles raised under aquaculture conditions. The juveniles were subjected to two starvation/refeeding regimes: a 7-day starvation period followed by 21 days of refeeding, and a14-day starvation period followed by 21 days of refeeding. The results had shown that the juveniles subjected to 7/21-day starvation/refeeding regime presented a complete compensatory growth, they were able to counteract the oxidative stress by enhancing activities of the antioxidant enzymes and they presented no significant changes in hsp gene expression. In contrast, 14/21-day starvation/refeeding regime negatively influenced growth performance, it induced a high level of oxidative stress that was impossible to counteract and it determined major changes in the hsp gene expression level in the liver of Acipenser stellatus. Thus, Acipenser stellatus seems to be able to adapt only to the 7/21-day starvation/refeeding regime that does not threaten the growth performance and the welfare of juveniles. Therefore, it could be useful to optimize the feeding practice in aquaculture production.

Key words: Acipenser stellatus; growth performance; oxidative stress; hsp gene expression; starvation/refeeding regime.

Received: 03 October, 2018; revised: 22 February, 2019; accepted: 25 February, 2019; available on-line: 10 March, 2019

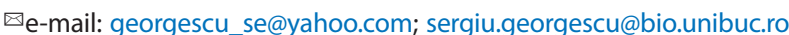
* Preliminary reports on this subject were presented at several scientific meetings: The 5th Aquatic Biodiversity International Conference, Lucian Blaga University of Sibiu, October 7th-10th 2015, Sibiu, Romania; The 7th International Zoological Congress of Grigore Antipa Museum, November 18th-21st 2015, Bucharest, Romania; Sesiunea de comunicări științifice a studenților Facultății de Biologie, June 3rd 2016, Faculty of Biology, Bucharest, Romania; The 8th International Zoological Congress of Grigore Antipa Museum, November 16th-19th 2016, Bucharest, Romania

Acknowledgements of Financial Support: This work was supported by Executive Agency for Higher Education, Research, Development and Innovation Funding from Romania, research projects "Technology for selection and genetic improvement in order to increase profitability of sturgeon's aquaculture" [53PTE/2016]; "Meth- odology for genetic certification of aquaculture sturgeon species in order to increase the value of sturgeon products and for participation in restocking programs" [184PED/2017].

Abbreviations: AOPP, Advanced oxidation protein products; BSA, Bovine serum albumin; CDNB, 1-chloro-2,4-dinitrobenzene; DNPH, 2,4-dinitrophenylhydrazine; DTNB， 5,5'-dithiobis-2-nitrobenzoic acid; F, Forward; GAPDH, Glyceraldehyde 3-phosphate dehydrogenase; GPx, Glutathione peroxidase; GR, Glutathione reductase; GSH Reduced glutathione; GSSG, Oxidized glutathione; HSI, Hepatosomatic index; Hsp, Heat shock protein; $\mathrm{K}$, Condition factor; MDA, Malondialdehyde; PCG, Protein carbonyl group; PCR, Polymerase chain reaction; PUFA, Polyunsaturated fatty acids; $R$, Reverse; RIN, RNA integrity number; ROS, Oxygen reactive species; rpm, Rotation per minute; SEM, Standard error of the mean; SGR, Specific growth rate; TBA, Thiobarbituric acid; $U$, Unit of enzyme

\section{INTRODUCTION}

Sturgeons, including stellate sturgeon Acipenser stellatus (Pallas, 1771), represent an ancient group of fish, dating back to Jurassic, that was able to survive two mass extinctions and several Ice Ages. A. stellatus lives in the Black Sea and migrates in the Danube River for reproduction purposes (Bemis \& Kynard, 1997). This species is valuable for the scientific community, representing a model for the evolution of vertebrates and it is highly precious for food industry due to its meat and roe used for caviar production. Because of its great economical value, stellate sturgeon has been massively captured, leading to a decline of this sturgeon population in the Black Sea. Furthermore, the construction of the Iron Gates Dams over the Danube River impaired the upstream migration and spawning of $A$. stellatus and therefore, its reproduction sites were diminished. Also, the pollution of natural habitats and the river bottom modifications have negatively influenced its reproduction (Bacalbașa-Dobrovici, 1997). As a consequence, A. stellatus became extinct in the Upper and Middle Danube and it is considered threatened in the Lower Danube River (Hensel \& Holcík, 1997). Conservation measures have been taken in order to protect this species. One of these measures consists of an artificial reproduction of wild genitors, followed by raising the juveniles in fish farms. These individuals are used for restocking purposes and also for the production of caviar, aiming to discourage poaching and overfishing of wild individuals.

The aquaculture field is focused on optimizing biotechnological parameters of culture systems, such as the feeding regime. Fish farmers aim to introduce food deprivation periods in the feeding practice for several reasons. First of all, the highest cost in an intensive aq- 
uaculture system corresponds to the purchase of food (Shepherd \& Bromage, 1988). In particular, the feeding practice represents at least $50 \%$ of the production cost (Gunther et al., 1992). Secondly, ad-libitum type of feeding is under debate, even though it represents the main practice in aquaculture. For example, overfeeding of fish in aquaculture may cause health problems, such as cardiac deformities and coronary arteriosclerosis due to fat deposits (Gamperl \& Farrell, 2004). Moreover, caloric restriction is believed to enhance stress resistance and to increase life span in invertebrates, fish and rodents (Masoro, 1992; Heydari et al., 1995; Weindruch et al., 2001; Abele et al., 2007). Finally, food deprivation is sometimes a common practice in fish farming in order to regulate fish stock before marketing and slaughtering, aiming to improve preservation (Bugeon et al., 2004); additionally, fasting can be induced in order to decrease water pollution and to reduce the mortality caused by disease outbreaks (Caruso et al., 2012).

Fish alternate fasting with feeding periods in their natural existence because of seasonal variations in food availability from natural habitats and due to reproduction and migration habits; therefore, fish are well adapted to starvation (Weatherly \& Gill, 1987; Madrid et al., 2001). They adopt different strategies in order to survive starvation periods: they reduce the energetic demands either by decreasing the mass of the tissues with high turnover rates or by lowering the metabolic rates (McCue, 2010). Based on the idea that fish are adapted to food deprivation in the natural environments, several studies have been conducted to assess if a regime based on a starvation period followed by refeeding affects the growth performance and the welfare of the fish bred under aquaculture conditions. Morphometric, hematological, biochemical and metabolic parameters or oxidative stress biomarkers were determined mainly in fish juveniles, but also in adults subjected to different starvation/refeeding regimes. Siberian sturgeon Acipenser baerii (Morshedi et al., 2013), Persian sturgeon Acipenser persicus (Yarmohammadi et al., 2013) and Chinese sturgeon Acipenser sinensis (Liu et al., 2011) present a complete compensatory growth as a response to short-term starvation (one week or less), meaning that after refeeding the final weight and the gain weight of the starved juveniles are similar to those of the constantly fed juveniles. The mechanism of compensatory growth has been described by Hornick and others (Hornick et al., 2000) as involving the growth hormone, insulin and insulin-like growth factor.

However, beluga Huso huso did not present a complete catch-up growth when subjected to different starvation/ refeeding regimes, although the growth rate of the individuals was high (Falahatkar, 2012). On the other hand, A. sinensis (Liu et al., 2011) and A. persicus (Yarmohammadi et al., 2013) showed a partial compensation when subjected to long-term starvation periods. In contrast to the above mentioned species, other fish species, such as channel catfish Ictalurus punctatus (Gaylord et al., 2001) and red porgy Pagrus pagrus (Caruso et al., 2012), failed to present a complete compensatory growth response when subjected to different starvation/refeeding regimes.

Adaptive responses to short or long-term starvation regarding hematological, biochemical or metabolic parameters were found in A. baerii (Ashouri et al., 2013), Adriatic sturgeon Acipenser naccarii and rainbow trout $O n$ corbynchus mykiss (Furné et al., 2012), European eel $A n$ guilla anguilla (Caruso et al., 2010), tench Tinca tinca (De Pedro et al., 2003), common dentex Dentex dentex (PérezJiménez et al., 2012) and European bass Dicentrarchus labrax (Pérez-Jiménez et al., 2007).
Moreover, starvation/refeeding regimes were proved to enhance cell protective mechanisms, such as antioxidant defense mechanisms and Heat Shock Protein (Hsp) expression in D. labrax (Antonopoulou et al., 2013). The reported results differ mainly due to species and age variations of the analyzed juveniles. Generally, fish present a metabolic adjustment to minimize the energy expenditure during starvation and an adaptive response to cope to the oxidative stress induced by a starvation/refeeding regime.

In this context, the study presented here was conducted based on the idea that $A$. stellatus adults are adapted to starvation in natural environment due to migration and reproduction habits. Taking into account this idea, the present study started from the hypothesis that $A$. stellatus juveniles raised in aquaculture conditions could also adapt to a starvation period introduced in their feeding regime. Therefore, this study aimed to determine if $A$. stellatus juveniles raised in aquaculture have the ability to adapt to a starvation/refeeding regime by assessing the effects of this alternative type of feeding on morphometric parameters, oxidative stress biomarkers and expression of $h s p$ genes. This type of study has been never conducted on stellate sturgeon before, as far as we know. In addition, this species is intensively raised in fish farms in Romania, being of great socio-economical interest for local communities. Our study was focused on the evaluation of $A$. stellatus liver, since it represents the most metabolically active organ and also an important storage organ. The results of this study might represent a starting point to optimize the feeding regime in aquaculture for $A$. stellatus juveniles. A regime based on starvation and refeeding periods could decrease the cost of raising juveniles and eventually increase the profitability of fish farms, stimulating aquaculture practice. In the long run, this could enhance the efforts to conserve A. stellatus.

\section{MATERIALS AND METHODS}

Animal experimental procedures were performed in accordance with the Guide for The Use and Care of Laboratory Animals (National Research Council (US) Committee for the Update of the Guide for the Care and Use of Laboratory Animals 2011) and all efforts were made to minimize animal suffering and reduce the number of specimens used. All animal experiments were approved by the Ethics Committee from the "Lower Danube" University of Galati (Approval ID: 200/22.12.2014).

Experimental design. A total number of $48 \mathrm{~A}$. stellatus individuals of the age of 1 year and the mean weight of $331.3 \pm 71.8 \mathrm{~g}$ were purchased from a sturgeon farm (Tulcea County, Romania). They were randomly distributed in six fiberglass reinforced polyester tanks of $1 \mathrm{~m}^{3}$ capacity in a recirculating system ( 8 individuals per tank). The tanks were maintained at the natural day length in May-June at our latitude. The water flow was $6 \mathrm{~m}^{3} \mathrm{~h}^{-1}$ and the evacuated water was treated with special filters and sterilized with UV light before admission into the system; the water temperature, $\mathrm{pH}$ level and oxygen concentration were maintained at a mean value of $25^{\circ} \mathrm{C} \pm 1$, $7.70 \pm 0.29$, and $6.60 \pm 0.44 \mathrm{mg} \mathrm{L}^{-1}$, respectively; the concentrations of ammonium, nitrites and nitrates were monitored during the whole experiment and maintained at a mean value of $0.43 \pm 0.12 \mathrm{mg} \mathrm{L}{ }^{-1}, 0.32 \pm 0.15 \mathrm{mg} \mathrm{L}^{-1}$ and $32.20 \pm 17 \mathrm{mg} \mathrm{L}^{-1}$, respectively. 
The juveniles were acclimatized for two months before the initiation of the experiment. After this period, the juveniles were subjected to the following treatments:

1. the fed control group (Fed C) was subjected to the classical feeding regime applied in aquaculture: juveniles were fed three times per day (at 9:00, 13:00 and 17:00 h) with Troco PreGrower commercial pellets (Table 1), the quantity of food given during a meal being equal to $1 \%$ of the total biomass; this regime was applied for the entire period of experiment; 2. a group was subjected to a 7-day starvation period and sampled (7 S group);

3. a group was subjected to a 14-day starvation period and sampled (14 S group);

4. a group was starved for 7 days and refed for 21 days (7 S-R group) - this regime being the $7 / 21$-day starvation/refeeding regime;

5. a group was starved for 14 days and refed for 21 days (14 S-R group) - this regime being the 14/21-day starvation/refeeding regime;

6. a group was starved for the entire period of the experiment (S C group - starved control group). The refeeding process of the $7 \mathrm{~S}-\mathrm{R}$ group and $14 \mathrm{~S}-\mathrm{R}$ group was performed in the same manner as in the Fed $\mathrm{C}$ group. The entire experiment lasted 35 days.

The fish were weighed and measured before the beginning of the experiment and before sampling. They were anesthetized in a bath with $0.3 \mathrm{~mL} \mathrm{~L}^{-1} 2$-phenoxyethanol before sampling. Afterwards, they were sacrificed by cutting the gill arch and the livers were collected, weighed and put into sterile tubes on ice and kept at $-80^{\circ} \mathrm{C}$ for biochemical analyses. The samples for molecular biology studies were preserved in the RNAlater solution and kept at $-80^{\circ} \mathrm{C}$ for further analyses. All analyses were performed in triplicates.

Morphometric parameters. The parameters indicating the growth performance were measured using the following equations:

- Weight gain $(\%)=\left(\mathrm{W}_{\mathrm{t}}-\mathrm{W}_{0}\right) \mathrm{W}_{0}^{-1} \times 100$

- HSI $(\%)=\mathrm{W}_{1} \mathrm{~W}_{\mathrm{b}}^{-1} \times 100$

$-\operatorname{SGR}\left(\% \mathrm{day}^{-1}\right)=\left(\ln \mathrm{W}_{\mathrm{t}}-\ln \mathrm{W}_{0}\right) t^{-1} \times 100$

$-\mathrm{K}=\mathrm{W} \mathrm{L} \mathrm{L}^{-3} \times 100$

- Survival rate $(\%)=($ number of fish at the end of the experiment/initial number of fish) $\times 100$

where $W_{t}$ is the final body weight at time $t, W_{0}$ is the initial body weight, $W_{1}$ is the weight of the liver, $W_{b}$ is the weight of the body before sampling, $\mathrm{t}$ is the period of the feeding regime and $\mathrm{L}$ is the length of the body.

Biochemical analyses. Fragments of $0.1 \mathrm{~g}$ from the liver tissue were mixed with $1 \mathrm{~mL}$ of ice-cold TrisEDTA buffer $(0.1 \mathrm{M}$ Tris- $\mathrm{HCl}$ buffer containing $5 \mathrm{mM}$ EDTA, pH 7.4) and homogenized (three times, $30 \mathrm{sec}-$ onds each) on ice using an UP50H sonicator (Hielscher). After 30 minute centrifugation of the tissue homogenates at $10000 \mathrm{rpm}, 4^{\circ} \mathrm{C}$, the resulting supernatants were collected and preserved at $-80^{\circ} \mathrm{C}$ for further analyses. The total protein concentration was measured according to the method described by Lowry and others (Lowry et al., 1951) using bovine serum albumin (BSA) as standard.

Antioxidant enzyme assays. The activities of antioxidant enzymes were assessed at $25^{\circ} \mathrm{C}$ using a Jasco V-530 spectrophotometer or a Tecan Genios multireader and the reagents were purchased from Sigma Aldrich or Merck.

Catalase (CAT; EC 1.11.1.6) activity was determined by monitoring the decrease in hydrogen peroxide $\left(\mathrm{H}_{2} \mathrm{O}_{2}\right)$ concentration at $240 \mathrm{~nm}$ according to the method described by Beers \& Sizer (Beers \& Sizer, 1952). One unit
Table 1. The biochemical composition of TrocoPre Grower commercial pellets

\begin{tabular}{ll}
\hline Substance & Quantity \\
\hline Proteins & $45 \%$ \\
\hline Lipids & $18 \%$ \\
\hline Raw fiber & $1.2 \%$ \\
\hline Ash & $8.2 \%$ \\
\hline Phosphorus & $1.2 \%$ \\
\hline Calcium & $1.8 \%$ \\
\hline Sodium & $0.4 \%$ \\
\hline Vitamin A & $10.000 \mathrm{I.E}$ \\
\hline Vitamin D3 & $746 \mathrm{I.E}$ \\
\hline Vitamin C & $150 \mathrm{mg} / \mathrm{kg}$ \\
\hline Vitamin E & $200 \mathrm{mg} / \mathrm{kg}$ \\
\hline
\end{tabular}

of enzyme (U) decomposes one $\mu$ mole of $\mathrm{H}_{2} \mathrm{O}_{2}$ in one minute at $25^{\circ} \mathrm{C}$ and $\mathrm{pH} 7$.

Superoxide dismutase (SOD; EC 1.15.1.1) activity was measured by monitoring the inhibition of NADH oxidation for 21 minutes at $340 \mathrm{~nm}$ (Paoletti et al., 1986). $\mathrm{NADH}$ oxidation was mediated by superoxide anion that was generated from molecular oxygen in a chemical reaction involving $\beta$-mercaptoethanol, triethanolamine, diethanolamine, EDTA and manganese chloride. One unit of SOD was described as the amount of enzyme required to inhibit the $\mathrm{NADH}$ oxidation rate by $50 \%$ when compared to control.

Glutathione peroxidase (GPx; EC 1.11.1.9) activity was determined by monitoring the reduction of tertbutyl-hydroperoxide and the oxidation of reduced glutathione (GSH) to oxidized glutathione (GSSG) (Beutler, 1984). Further on, the resulting GSSG was reduced to GSH by glutathione reductase and conversion of NA$\mathrm{DPH}$ to $\mathrm{NADP}^{+}$was measured at $340 \mathrm{~nm}$. One unit of GPx was defined as the amount of enzyme required to consume one $\mu$ mole of NADPH in one minute at $25^{\circ} \mathrm{C}$.

Glutathione reductase (GR; EC 1.6.4.2) activity was determined by monitoring the decrease in NADPH concentration at $340 \mathrm{~nm}$ following the conversion of GSSG to GSH (Goldberg \& Spooner, 1983). One unit of GR was defined as the amount of enzyme required to consume one $\mu$ mole of NADPH in one minute at $25^{\circ} \mathrm{C}$.

Glutathione S-transferase (GST; EC 2.5.1.18) activity was determined by monitoring the conjugation of GSH with 1-chloro-2, 4-dinitrobenzene (CDNB) substrate at $340 \mathrm{~nm}$ (Habig et al., 1974). One unit of GST was defined as the amount of enzyme necessary to form one umole of GS-CDNB product in one minute at $25^{\circ} \mathrm{C}$.

Glucose 6-phosphate dehydrogenase (G6PDH; EC 1.1.1.49) activity was measured by monitoring the increase of NADPH concentration at $340 \mathrm{~nm}$. This enzyme catalyses the oxidation of glucose 6-phosphate by reducing $\mathrm{NADP}^{+}$(Lohr \& Waller, 1974). One unit of G6PDH was defined as the amount of enzyme required to produce one $\mu$ mole of NADPH in one minute at $25^{\circ} \mathrm{C}$.

The specific activities of all enzymes were calculated as $\mathrm{U} \mathrm{mg}^{-1}$ protein using the specific molar extinction coefficients $\left(\varepsilon_{\mathrm{H}_{2} \mathrm{O}_{2}}=43.6 \times 10^{3} \mathrm{M}^{-1} \mathrm{~cm}^{-1}, \quad \varepsilon_{\mathrm{CDNB}}=9.6 \times 10^{3}\right.$ $\left.\mathrm{M}^{-1} \mathrm{~cm}^{-1} \varepsilon_{\mathrm{NADPH}}=6.2210^{3} \mathrm{M}^{-1} \mathrm{~cm}^{-1}\right)$.

Oxidative changes of biomolecules. Reduced glutathione assay. The GSH content was evaluated using Glutathione Assay Kit from Sigma-Aldrich, according 
to the manufacturer's instructions. Briefly, deproteinized tissue lysates were mixed with $1.5 \mathrm{mg} \mathrm{mL}^{-1}$ 5,5'-dithiobis-2-nitrobenzoic acid (DTNB) in potassium phosphate buffer solution and the amount of the resulted TNB products was measured at $405 \mathrm{~nm}$. A calibration curve with standard GSH solution of various concentrations in the range of $3.1-50 \mu \mathrm{M}$ was used in order to determine the GSH concentration in the samples.

Lipid peroxidation markers. Malondialdehyde (MDA) is a lipid peroxidation end product that was determined using 2-thiobarbituric acid (TBA) according to a classical method (del Rio et al., 2003). A $200 \mu \mathrm{L}$ sample was mixed with $700 \mu \mathrm{L}$ of $0.1 \mathrm{~N} \mathrm{HCl}$ and incubated for 20 minutes at room temperature. After adding $900 \mu \mathrm{L}$ of $0.025 \mathrm{M}$ TBA, the mixture was incubated for another 65 minutes at $37^{\circ} \mathrm{C}$. The fluorescence of MDATBA adducts was recorded at $520 \mathrm{~nm}$ excitation and 549 nm emission using Jasco FP-750 spectrofluorometer. A calibration curve with standard MDA (1,1,3,3-tetraethoxypropane) in the range of 0.5 to $5 \mu \mathrm{M}$ was used to calculate the concentration of MDA in the samples.

Protein oxidation markers. Protein carbonyl group (PCG) concentration was determined by measuring the hydrazones resulted in the reaction of 2,4-dinitrophenylhydrazine (DNPH) with protein carbonyls (Fields \& Dixon, 1971). Protein extracts, $500 \mu \mathrm{L}$, were mixed with an equal volume of $10 \mathrm{mM}$ DNPH and incubated for one hour at room temperature in the dark. After protein precipitation with $500 \mu \mathrm{L}$ of ice-cold $20 \%$ trichloroacetic acid (TCA), the samples were centrifuged for 5 minutes at $13000 \mathrm{rpm}, 4^{\circ} \mathrm{C}$. The pellet was washed two times with one $\mathrm{mL}$ of ethanol: ethyl acetate $(1: 1)$ mixture and centrifuged for 5 minutes at $13000 \mathrm{rpm}, 4^{\circ} \mathrm{C}$. The pellet was solubilized in $500 \mu \mathrm{L}$ of $1 \mathrm{M} \mathrm{NaOH}$ and the absorbance of the carbonyl-DNPH products was measured at $370 \mathrm{~nm}$. The concentration of PCG was calculated using $\varepsilon_{\mathrm{DNPH}}=22000 \mathrm{M}^{-1} \mathrm{~cm}^{-1}$ as molar extinction coefficient. The concentration of PCG was divided by the total protein concentration of the sample and it was expressed in nmoles $\mathrm{mg}^{-1}$ protein.

Advanced oxidation protein products (AOPP) were measured spectrophotometrically (Witko et al., 1992). A $200 \mu \mathrm{L}$ sample was incubated with $10 \mu \mathrm{L}$ of $1.16 \mathrm{M}$ potassium iodide $(\mathrm{KI})$ for 5 minutes at room temperature under constant mixing. $20 \mu \mathrm{L}$ of glacial acetic acid were added to the mixture and incubated for 30 seconds. The optical density was recorded at $340 \mathrm{~nm}$. A calibration curve with chloramine $\mathrm{T}$ of various concentrations (5$100 \mu \mathrm{M})$ was used to quantify the AOPP content. The concentration of AOPP was divided by the total protein concentration of the sample and it was expressed as $\mu \mathrm{M}$ $\mathrm{mg}^{-1}$ protein.
The assessment of hsp gene expression by Real Time PCR analysis. Liver fragments were thawed on ice and were mixed with the lysis buffer and homogenized with magnetic balls using Retsch MM 400 mixer mill (30 Hz s$~^{-1}$ for 1 minute). RNA isolation and purification was performed with Pure Link RNA Minikit (Ambion, Life Technologies) according to the producer's instructions. The purification was performed using column membranes and absolute ethanol, and elution was performed with RNase free water. Aliquots were made in order to prevent degradation induced by freeze-thaw cycles. In the end, the concentration and purity of the total RNA was determined using NanoDrop 8000 spectrophotometer (Thermo Scientific).

RNA integrity number (RIN) assay. RIN values of the purified RNA samples were determined by microchip gel electrophoresis using Agilent RNA 6000 Nano kit and Agilent 2100 Bioanalyzer (Agilent). Samples with RIN values smaller than 8 were not included in further analysis and the homogenization and purification steps were repeated.

Reverse-transcription. Reverse transcription reaction was performed using iScript cDNA synthesis kit (Bio$\mathrm{Rad})$. A $4 \mu \mathrm{L}$ reaction mix and $1 \mu \mathrm{L}$ reverse transcriptase were mixed with $1 \mu \mathrm{L}$ RNA samples and completed with RNase - free water to a total volume of $20 \mu \mathrm{L}$. The final concentration of RNA was $1000 \mathrm{ng}$ per reaction. The reaction was performed using a Veriti 96 Well thermal cycler (Applied Biosystems) with the following program: one cycle of $25^{\circ} \mathrm{C}$ for 5 minutes, one cycle of $42^{\circ} \mathrm{C}$ for 30 minutes and one cycle of $85^{\circ} \mathrm{C}$ for $5 \mathrm{~min}$ utes.

The concentration and purity of the obtained cDNA samples was determined using NanoDrop 8000 spectrophotometer (Thermo Scientific).

Real Time PCR. Primers were designed using the BLAST program (Altschul et al., 1990) in order to amplify hsp70, hsp90a and hsp90b genes and two reference genes encoding for glyceraldehyde 3-phosphate dehydrogenase $(\mathrm{GAPDH})$ and $\beta$-actin in sturgeon species.

The sequences of the primers are presented in Table 2. The optimum annealing temperatures of the primers were determined by temperature gradient PCR.

Real Time PCR reaction was performed using iQ SYBR Green Super Mix (Bio-Rad). In a 96 well plate, $1 \mu \mathrm{L}$ of $100 \mathrm{ng} \mu \mathrm{L}^{-1} \mathrm{cDNA}, 12.5 \mu \mathrm{L}$ iQ SYBR Green Super Mix (Bio-Rad), $0.5 \mu \mathrm{L}$ of $20 \mathrm{pmol}^{2} \mathrm{~L}^{-1}$ forward primer, $0.5 \mu \mathrm{L}$ of $20 \mathrm{pmol} \mu \mathrm{L}^{-1}$ reverse primer and $10.5 \mu \mathrm{L}$ of MiliQ water were added. The total volume was $25 \mu \mathrm{L}$. Samples were amplified using iCycler System (BioRad) and the following program: one cycle of $95^{\circ} \mathrm{C}$ for 5 minutes, 45 cycles of $95^{\circ} \mathrm{C}$ for 30 seconds,

Table 2. The sequences and the optimum annealing temperature of the primers used for Real-Time PCR analysis

\begin{tabular}{|c|c|c|c|}
\hline Amplified gene & Primer sequence & Product length [bp] & Temperature $\left[{ }^{\circ} \mathrm{C}\right]$ \\
\hline hsp70 & $\begin{array}{l}\text { F: CCACTTYRTTGCRGAGTTCA } \\
\text { R: GTCCAGAGTACCACGGAACA }\end{array}$ & 229 & 56 \\
\hline hsp90a & $\begin{array}{l}\text { F: AGACAAGGCCAAGTT } \\
\text { R: GGCCTTCATGATCCTCTCCA }\end{array}$ & 160 & 55 \\
\hline hsp90b & $\begin{array}{l}\text { F: GGTTGCAGAGAAGGTTGTGG } \\
\text { R: GGTGATGGGGTAGCCGATAA }\end{array}$ & 229 & 55 \\
\hline GAPDH & $\begin{array}{l}\text { F: AGACACCCGCTCNTCHATCT } \\
\text { R: TCCACGACTCTGTTGCTGTA }\end{array}$ & 114 & $55-56$ \\
\hline$\beta$-actin & $\begin{array}{l}\text { F: TGACCCTGAAGTAYCCMATC } \\
\text { R: CTTCTCTCTGTTRGCYTTGG }\end{array}$ & 160 & $55-56$ \\
\hline
\end{tabular}

Note: $\mathrm{F}=$ forward primer, $\mathrm{R}=$ reverse primer, $\mathrm{bp}=$ base pairs 
Table 3. Morphometric parameters indicating growth performance of the Acipenser stellatus juveniles subjected to different starvation/refeeding regimes

\begin{tabular}{|c|c|c|c|c|c|c|}
\hline & Fed C & $7 \mathrm{~S}$ & $14 \mathrm{~S}$ & $7 \mathrm{~S}-\mathrm{R}$ & $14 \mathrm{~S}-\mathrm{R}$ & $\mathrm{SC}$ \\
\hline Initial weight (g) & $355.12 \pm 29.93$ & $325.62 \pm 25.23$ & $327.12 \pm 20.18$ & $311.12 \pm 22.10$ & $321.62 \pm 27.33$ & $349.42 \pm 33.87$ \\
\hline Final weight (g) & $402.86 \pm 33.20$ & $310.74 \pm 23.61$ & $299.13 \pm 19.72$ & $342.91 \pm 21.50$ & $328.03 \pm 25.31$ & $316.50 \pm 32.54$ \\
\hline Weight gain (\%) & $13.57 \pm 1.10$ & $-4.45 \pm 0.95^{* * * *}$ & $-8.71 \pm 1.04^{* * *}$ & $10.75 \pm 1.81$ & $2.58 \pm 1.29^{* * *}$ & $-9.64 \pm 1.53^{* * *}$ \\
\hline HSI (\%) & $1.30 \pm 0.07$ & $0.79 \pm 0.06^{* * *}$ & $0.80 \pm 0.03^{* *}$ & $1.34 \pm 0.07$ & $1.45 \pm 0.13$ & $0.76 \pm 0.05^{* * *}$ \\
\hline SGR (\% day $\left.{ }^{-1}\right)$ & $0.43 \pm 0.03$ & $-0.65 \pm 0.14 * * *$ & $-0.61 \pm 0.07^{* * *}$ & $0.34 \pm 0.05$ & $0.07 \pm 0.03^{*}$ & $-0.29 \pm 0.05^{* * *}$ \\
\hline Initial K & $0.176 \pm 0.003$ & $0.179 \pm 0.005$ & $0.180 \pm 0.004$ & $0.175 \pm 0.005$ & $0.175 \pm 0.004$ & $0.170 \pm 0.005$ \\
\hline Final $\mathrm{K}$ & $0.200 \pm 0.003$ & $0.171 \pm 0.005^{* *}$ & $0.164 \pm 0.004^{* * *}$ & $0.193 \pm 0.005$ & $0.180 \pm 0.003^{*}$ & $0.154 \pm 0.006^{* * *}$ \\
\hline Survival rate (\%) & 100 & 100 & 100 & 100 & 100 & 87.5 \\
\hline
\end{tabular}

Note: The data are illustrated as average values of the groups $(n=8) \pm$ standard error of the mean (S.E.M.). All data were statistically analyzed using one-way ANOVA. ${ }^{*} P<0.05$; ${ }^{* *} P<0.01 ;{ }^{* *} P<0.001$; the statistical significance of the changes is related to the fed control level. Fed $C-$ fed control group, $7 \mathrm{~S}$ - group starved for 7 days, $14 \mathrm{~S}$ - group starved for 14 days, $7 \mathrm{~S}-\mathrm{R}$ - group starved for 7 days and refed for 21 days, $14 \mathrm{~S}-\mathrm{R}-\mathrm{group}$ starved for 14 days and refed for 21 days, S C - starved control, HSI - hepatosomatic index, SGR - specific growth rate, $\mathrm{K}$ - condition factor.

$55 / 56^{\circ} \mathrm{C}$ for 30 seconds, $72^{\circ} \mathrm{C}$ for 45 seconds and 85 cycles of $55^{\circ} \mathrm{C}$ with an increase of set point temperature by $0.5^{\circ} \mathrm{C}$ per cycle for 10 seconds. The samples were run and the threshold cycles $\left(\mathrm{C}_{t}\right)$ values were recorded. Melting curves were also performed. The $C_{t}$ values were processed with Microsoft Office Excel 2007 according to the

$2^{-\Delta \Delta \mathrm{Ct}}$ method described by Livak and Schmittgen (2001).

Statistical analysis. Technical replicates were averaged before statistical analysis. The data are illustrated as average values of the groups $(n=8) \pm$ standard error of the mean (SEM). All data were statistically analyzed using one-way ANOVA method performed with Graph Pad Prism 3.03 software (GraphPad Software, La Jolla California USA). Post-hoc comparisons between all groups were run using Bonferroni test. If $P$ value was lower than 0.05 then the difference between the groups was considered statistically significant $(* P<0.05$; $\left.* * P<0.01 ;{ }^{*} * * P<0.001\right)$. The statistical significance was presented for all groups in contrast to the Fed $\mathrm{C}$ group and it was also presented between $7 \mathrm{~S}$ and $14 \mathrm{~S}$ groups and between 7 S-R and 14 S-R groups.

\section{RESULTS}

\section{Morphometric data}

Parameters indicating growth performance are presented in Table 3. The final weights of the experimental groups were not statistically different regarding the final weight of the Fed $\mathrm{C}$ group. The weight gain severely decreased during starvation period, juveniles losing weight in a time-dependent manner. However, they restarted to gain weight during the refeeding period, but only the group subjected to the $7 / 21$-day starvation/refeeding regime showed no significant difference in the weight gain when compared to the Fed C group. Whilst starvation diminished SGR and HSI values, refeeding determined an increase in these parameters. Only the group subjected to $7 / 21$-day starvation/refeeding regime presented a growth rate similar to the Fed $C$ group. $K$ values of the experimental groups were significantly lower than the one of the Fed C group, except for the $7 \mathrm{~S}-\mathrm{R}$ group, whose condition factor was similar to the Fed $\mathrm{C}$ group.

\section{The antioxidant enzymes' specific activities}

CAT and SOD represent important antioxidant enzymes that are able to neutralize ROS. SOD catalyzes the reaction of dismutation of $\mathrm{O}^{2-}$ into $\mathrm{H}_{2} \mathrm{O}_{2}$, which is further decomposed in the reaction catalyzed by CAT into water and oxygen, preventing formation of the hydroxyl ion. The activities of these enzymes are considered as biomarkers for oxidative stress (Mueller et al., 1997; Cadenas \& Kelvin, 2000; Miyamoto et al., 2010) (S1).

In our study, it was observed that the specific activities of CAT and SOD were unmodified in the liver of the juveniles from the $7 \mathrm{~S}$ group when compared to the Fed C group $(P>0.05)$; only the activity of CAT was significantly increased in the liver of the juveniles from the $14 \mathrm{~S}$ group, the SOD activity remaining at the same level with the one observed in the Fed C group. No significant changes were observed between the $7 \mathrm{~S}$ and $14 \mathrm{~S}$ groups (Fig. 1).

Refeeding after starvation determined a major and statistically significant increase in the activities of both enzymes when compared to the constant feeding regime, the increase being proportional to the length of previous starvation period for the CAT enzyme (the activity of CAT in the 7S-R group was significantly lower than the one observed for the $14 \mathrm{~S}-\mathrm{R}$ group). No significant changes were observed between the S C and Fed C groups (Fig. 1).

Enhanced activities of both antioxidant enzymes during starvation/refeeding regimes observed in our study could reflect an increase in the level of enzymatic substrates $\left(\mathrm{O}^{2-}\right.$ and $\left.\mathrm{H}_{2} \mathrm{O}_{2}\right)$, equivalent to an overproduction of ROS. However, even though both, the 7/21-day and 14/21-day starvation/refeeding regimes induced an increase in SOD and CAT activities, CAT activity was significantly higher in the $14 \mathrm{~S}-\mathrm{R}$ group than in the $7 \mathrm{~S}-\mathrm{R}$ group, suggesting that the 14/21-day starvation/refeed- 

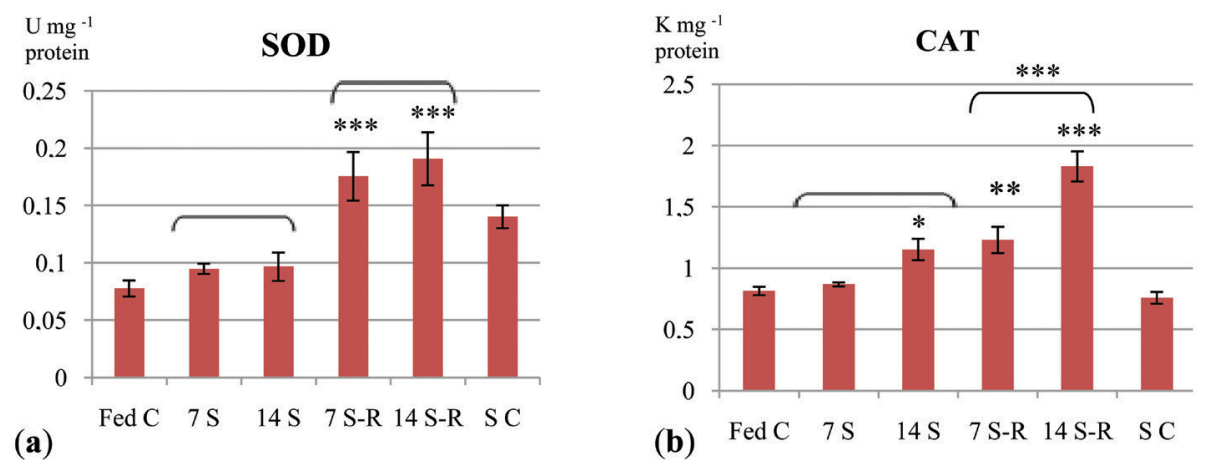

Figure 1. Specific activities of antioxidant enzymes in the liver of Acipenser stellatus juveniles subjected to different starvation/refeeding regimes:

(a) Superoxide dismutase (SOD) specific activity; (b) Catalase (CAT) specific activity. The data are illustrated as average values of the groups $(n=8) \pm$ standard error of the mean (S.E.M). All data were statistically analyzed using one-way ANOVA. Statistical significance: ${ }^{*} P<0.05 ;{ }^{*} P<0.01 ;{ }^{* * *} P<0.001$; the statistical significance of the changes is related to the fed control level and is also presented between the $7 \mathrm{~S}$ and $14 \mathrm{~S}$ groups, and between the $7 \mathrm{~S}-\mathrm{R}$ and $14 \mathrm{~S}-\mathrm{R}$ groups. Fed $\mathrm{C}-$ fed control group, $7 \mathrm{~S}-$ group starved for 7 days, $14 \mathrm{~S}-$ group starved for 14 days, $7 \mathrm{~S}-\mathrm{R}$ - group starved for 7 days and refed for 21 days, 14 S-R - group starved for 14 days and refed for 21 days, S C - starved control.

ing regime induced oxidative stress to a greater extent than the 7/21-day starvation/refeeding regime did.

GPx catalyzes a reaction between peroxides and GSH, while GR recycles the resulting GSSG by reducing the disulfide bond, thus producing 2 molecules of GSH. GPx substrates are both, lipid peroxides and $\mathrm{H}_{2} \mathrm{O}_{2}$, the latter being also removed by CAT (Meister, 1989; Cadenas \& Kelvin, 2000; Miyamoto et al., 2010) (S1). The 7-day starvation period induced a decrease in
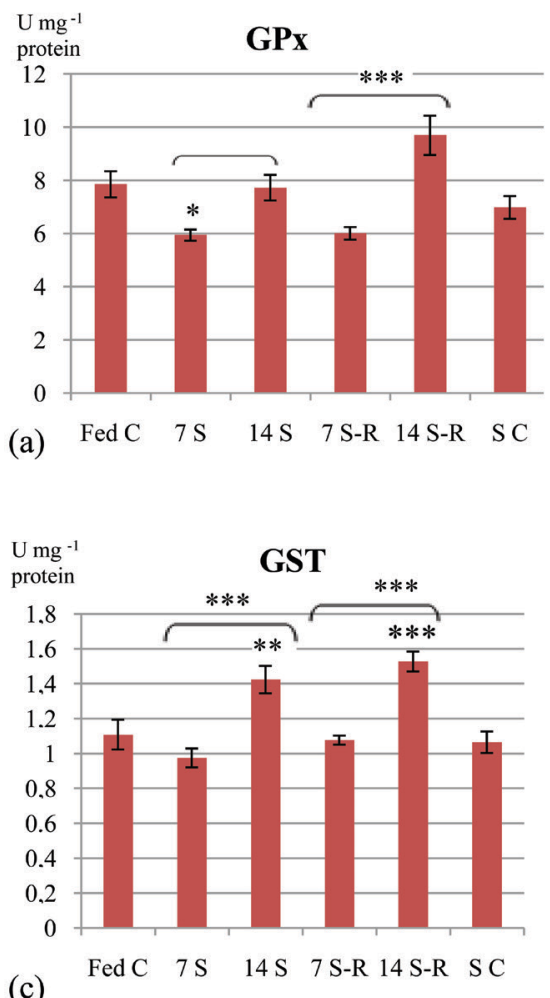

(c) both, the GPx and GR specific activities when compared to the constant feeding regime. The subsequent refeeding increased both, the GPx and GR activities, so the enzymatic activities eventually reached the Fed $\mathrm{C}$ level $(P>0.05)$. In contrast, after a 14-day starvation period, GR activity had increased when compared to the Fed $\mathrm{C}$ group and increased even greater during refeeding. The S C group presented insignificant changes in both enzyme activities in comparison to the Fed

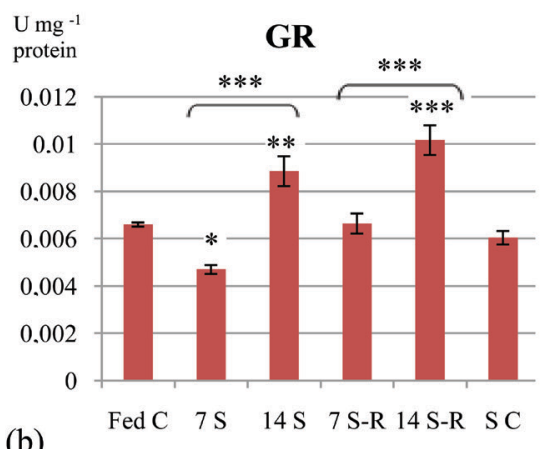

(b)

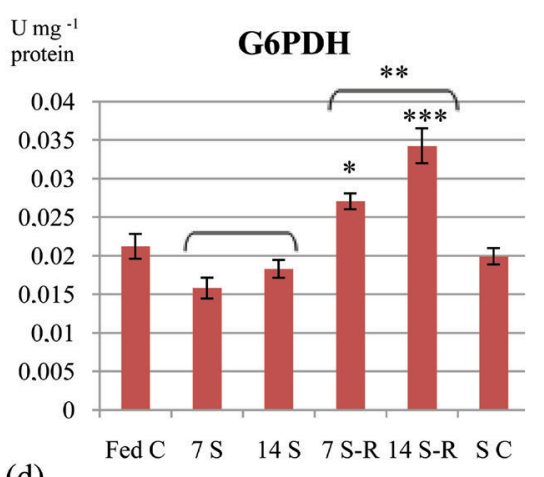

(d)

Figure 2. Specific activities of antioxidant enzymes in the liver of Acipenser stellatus juveniles subjected to different starvation/refeeding regimes:

(a) Glutathione peroxidase (GPx) specific activity; (b) Glutathione reductase (GR) specific activity; (c) Glutathione S-transferase (GST) specific activity; (d) Glucose 6-phosphate dehydrogenase (G6PDH) specific activity. The data are illustrated as average values of the groups $(n=8) \pm$ standard error of the mean (S.E.M). All data were statistically analyzed using one-way ANOVA. Statistical significance: $* P<0.05$; ${ }^{*} P<0.01$; $* * P<0.001$; the statistical significance of the changes is related to the fed control level and is also presented between the 7 $\mathrm{S}$ and $14 \mathrm{~S}$ groups, and between the $7 \mathrm{~S}-\mathrm{R}$ and $14 \mathrm{~S}-\mathrm{R}$ groups. Fed C - fed control group, $7 \mathrm{~S}-$ group starved for 7 days, $14 \mathrm{~S}-$ group starved for 14 days, 7 S-R - group starved for 7 days and refed for 21 days, 14 S-R - group starved for 14 days and refed for 21 days, S C - starved control. 


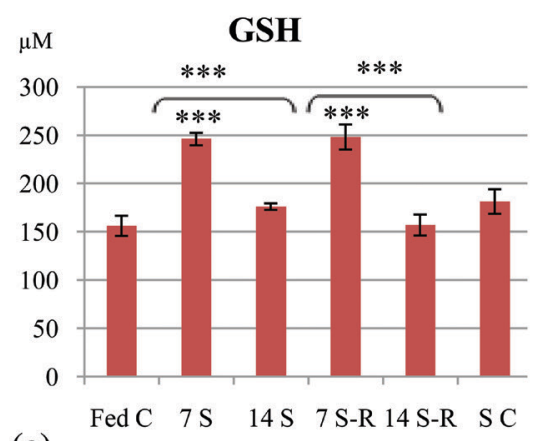

(a)

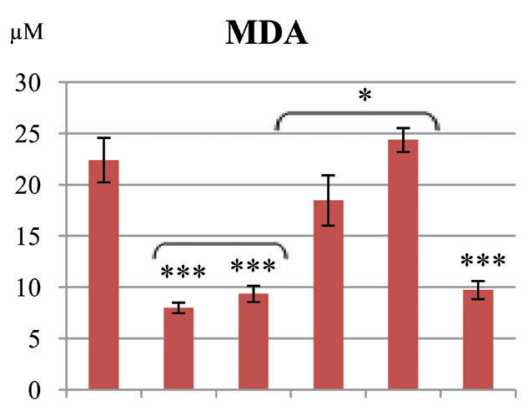

(b) Fed C $7 \mathrm{~S} 14 \mathrm{~S} 7 \mathrm{~S}-\mathrm{R} 14 \mathrm{~S}-\mathrm{R}$ S C

Figure 3. Oxidative changes in biomolecules in the liver of Acipenser stellatus juveniles subjected to different starvation/refeeding regimes:

(a) The level of reduced glutathione (GSH); (b) The level of malondialdehyde (MDA). The data are illustrated as average values of the groups $(n=8) \pm$ standard error of the mean (SEM). All data were statistically analyzed using one-way ANOVA. Statistical significance: ${ }^{*} P<0.05$; ${ }^{*} P<0.01 ;{ }^{* *} P<0.001$; the statistical significance of the changes is related to the fed control level and it is also presented between the $7 \mathrm{~S}$ and $14 \mathrm{~S}$ groups, and between the $7 \mathrm{~S}-\mathrm{R}$ and $14 \mathrm{~S}-\mathrm{R}$ groups. Fed C - fed control group, $7 \mathrm{~S}-$ group starved for 7 days, 14 $S$ - group starved for 14 days, 7 S-R - group starved for 7 days and refed for 21 days, 14 S-R - group starved for 14 days and refed for 21 days, S C - starved control.

C group (Fig. 2a, b). Because GR specific activity was unmodified in the $7 \mathrm{~S}-\mathrm{R}$ group and enhanced in the 14 S-R group when compared to the Fed C group, it could be said that the 7/21-day starvation/refeeding regime is more suited for juveniles, while the 14/21day starvation/refeeding regime induces a higher level of oxidative stress. In addition, GR activity was significantly increased in the $14 \mathrm{~S}$ group when compared to the $7 \mathrm{~S}$ group, and the activities of both, the GPx and GR enzymes were highly increased in the $14 \mathrm{~S}-\mathrm{R}$ group when compared to the $7 \mathrm{~S}-\mathrm{R}$ group, confirming that 14/21-day starvation/refeeding regime induced oxidative stress to a greater extent than the $7 / 21$-day starvation/refeeding one did.

The level of GST specific activity was unchanged in the $7 \mathrm{~S}$ and $7 \mathrm{~S}-\mathrm{R}$ groups when compared to the Fed $\mathrm{C}$ group. In contrast, the activity of GST was highly increased in the liver of the juveniles from the $14 \mathrm{~S}$ and $14 \mathrm{~S}-\mathrm{R}$ groups when compared to the control level. In addition, GST activity was greatly increased in the liver of the juveniles from the $14 \mathrm{~S}$ group when compared to the $7 \mathrm{~S}$ group, and also in the $14 \mathrm{~S}-\mathrm{R}$ group when compared to the $7 \mathrm{~S}-\mathrm{R}$ group, suggesting that the 14/21day starvation/refeeding regime induced GST substrates in contrast to the 7/21-day starvation/refeeding one that induced GST substrates at the same level as the constant feeding regime did (Fig. 2c).

Profile of the G6PDH activity suggests that the activity of this enzyme was unmodified during starvation, whereas it was strongly intensified during refeeding, the intensification being proportional to the starvation period length (Fig. 2d).

\section{Oxidative changes in the biomolecules}

GSH represents an important cellular antioxidant. It is a tripeptide involved not only in the GPx mediated removal of lipid peroxides and $\mathrm{H}_{2} \mathrm{O}_{2}$, but also in the reduction of oxidized sulfhydryl groups of proteins (Bansal \& Kaushal, 2014). It is also used by GST to conjugate electrophilic compounds in order to render less chemically active compounds and to ensure their clearance from the organism (Guérod, 2010) (S1). In our experiment, we noticed that GSH concentration decreased in the $14 \mathrm{~S}$ group when compared to the $7 \mathrm{~S}$ group and also in the $14 \mathrm{~S}-\mathrm{R}$ group when compared to the $7 \mathrm{~S}-\mathrm{R}$ group (Fig. 3a); meanwhile, the activity of GST increased in the $14 \mathrm{~S}$ group when compared to the $7 \mathrm{~S}$ group, and respectively in the $14 \mathrm{~S}-\mathrm{R}$ group when compared to the 7 S-R group. Also, the GPx activity was increased in the 14 S-R group when compared to the $7 \mathrm{~S}-\mathrm{R}$ group, therefore the level of GSH was inversely proportional to GPx and GST activities, suggesting an intense use of GSH by these enzymes.

MDA is an iconic biomarker of lipid peroxidation. It is an aldehyde produced after ROS mediated oxidation of the polyunsaturated fatty acids (PUFA). The long chains of PUFA are prone to sequential oxidations that could lead to cleavage and render small end products, such as MDA (Guérod, 2010; Bansal \& Kaushal, 2014) (S1). Starvation induced a decrease in the MDA level in comparison to the constant feeding regime, while refeeding increased the MDA level so it reached the control level (Fig. 3b).

PCG and AOPP represent hallmarks of the oxidative stress and are irreversible changes in the proteins (Witko-Sarsat et al., 2003; Bansal \& Kaushal, 2014). PCG consists of aldehydes and ketones that are produced during interaction between the hydroxyl ions and amino acids, such as lysine, arginine, proline and threonine (Requena et al., 2001). AOPP are considered to be crosslinked products of proteins that contain dityrosine (Witko-Sarsat et al., 2003). Also, they could be small products resulting from cleavage of a long polypeptidic chain due to protein oxidation mediated by the hypochlorous acid (Thomas, 1979; Thornalley \& Rabbani, 2010) (S1). In our study, the concentration of PCG did not statistically differ in the juveniles from the experimental groups when compared to the Fed C group; however, the PCG concentration strongly increased in the $14 \mathrm{~S}$ group when compared to the $7 \mathrm{~S}$ group, and respectively in the 14 S-R group when compared to 7 S-R group (Fig. 4a). The AOPP level decreased after a 7-day starvation period, while it reached the control level when the juveniles were refed. In contrast, the AOPP level was similar to the control level after a 14-day starvation period, but it was strongly increased when refeeding was resumed. Also, like the PCG level, the AOPP level was also increased in the $14 \mathrm{~S}$ group when compared to the $7 \mathrm{~S}$ group, and respectively in the $14 \mathrm{~S}-\mathrm{R}$ group when compared to the 7 S-R group (Fig. 4b).

\section{The level of $h s p 70$ and $h s p 90$ gene expression}

Molecular data showed that expression levels had similar profiles for $h s p 70, h s p 90 a$ and $h s p 90 b$ genes. No 


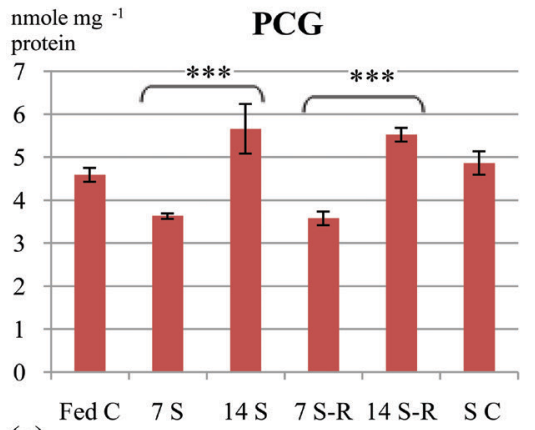

(a)

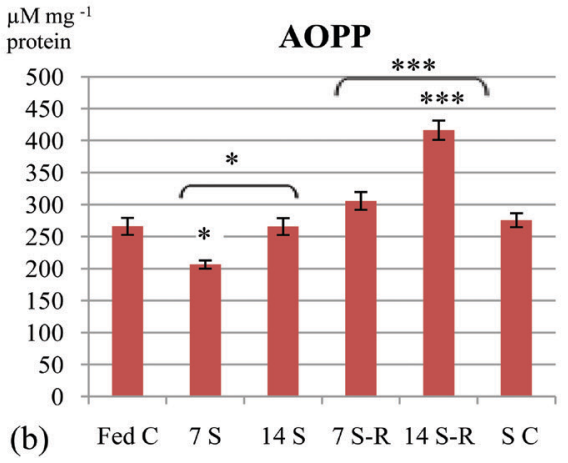

Figure 4. Oxidative changes in proteins in the liver of Acipenser stellatus juveniles subjected to different starvation/refeeding regimes

(a) The concentration of protein carbonyl group (PCG); (b) The concentration of advanced oxidation protein products (AOPP). The data are illustrated as average values of the groups $(n=8) \pm$ standard error of the mean (S.E.M.). All data were statistically analyzed using oneway ANOVA. Statistical significance: ${ }^{*} P<0.05 ;{ }^{*} P<0.01 ;{ }^{* * *} P<0.001$; the statistical significance of the changes is related to the fed control level and it is also presented between the $7 \mathrm{~S}$ and $14 \mathrm{~S}$ groups, and between the $7 \mathrm{~S}-\mathrm{R}$ and $14 \mathrm{~S}-\mathrm{R}$ groups. Fed C - fed control group, $7 \mathrm{~S}$ - group starved for 7 days, $14 \mathrm{~S}$ - group starved for 14 days, $7 \mathrm{~S}-\mathrm{R}$ - group starved for 7 days and refed for 21 days, 14 S-R - group starved for 14 days and refed for 21 days, S C - starved control.

significant changes were observed during a 7-day starvation period and also after subsequent refeeding when compared to the constant feeding regime. In contrast, gene expression increased during the 14-day starvation period and decreased during subsequent refeeding in the liver of $A$. stellatus juveniles when compared to the Fed C group. The expression of bsp70 and hsp90a genes was highly increased during 14-day starvation in comparison to 7-day starvation (Fig. 5).

A summary of the biochemical and molecular analysis results is presented in Table 4.

\section{DISCUSSION}

The results of this study demonstrate that $A$. stellatus presents compensatory growth when subjected to refeeding after starvation. However, only the 7S-R group presented a complete recovery of the weight loss during refeeding, as illustrated by the final weight, weight gain and SGR. A recovery of weight loss during refeeding after starvation, leading to compensatory growth, was also reported in $A$. persicus (Yarmohammadi et al., 2013) and in A. baerii (Morshedi et al., 2013) juveniles.

hsp70 gene expression level

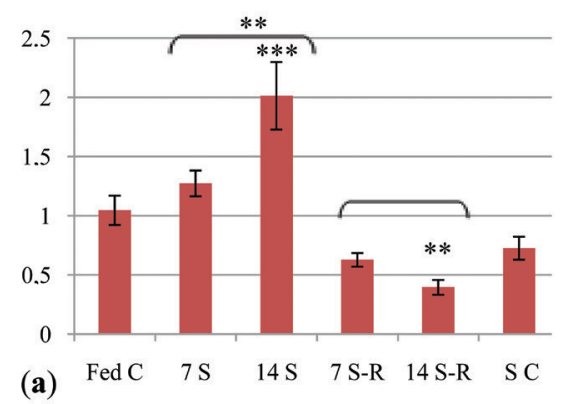

hsp90a gene expression level

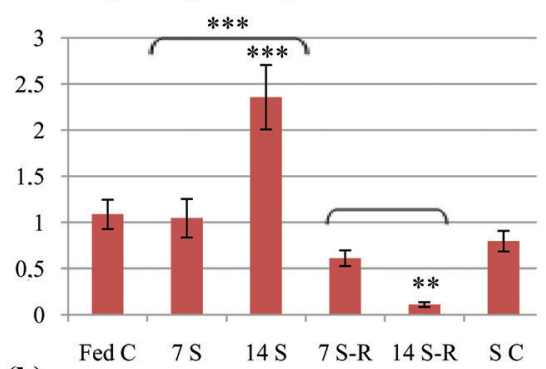

(b)

\section{$h s p 90 b$ gene expression level}

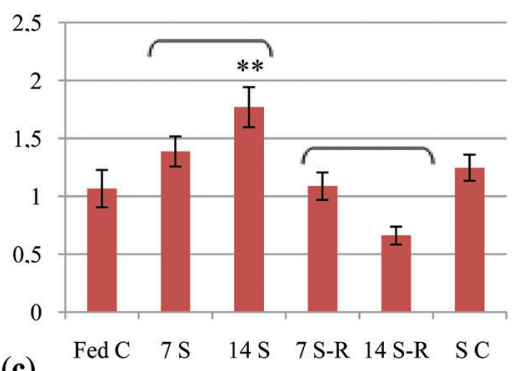

(c)

Figure 5. Level of $h s p$ gene expression in the liver of Acipenser stellatus juveniles subjected to different starvation/refeeding regimes (a) Expression level of the hsp70 gene; (b) Expression level of the hsp90a gene; (c) Expression level of the hsp90b gene. The data are illustrated as average values of the groups $(n=8) \pm$ standard error of the mean (SEM). All data were statistically analyzed using one-way ANOVA. Statistical significance: ${ }^{*} P<0.05 ;{ }^{* *} P<0.01 ;{ }^{* * *} P<0.001$; the statistical significance of the changes is related to the fed control level and it is also presented between the $7 \mathrm{~S}$ and $14 \mathrm{~S}$ groups, and between the $7 \mathrm{~S}-\mathrm{R}$ and $14 \mathrm{~S}-\mathrm{R}$ groups. Fed C - fed control group, $7 \mathrm{~S}-\mathrm{group}$ starved for 7 days, $14 \mathrm{~S}$ - group starved for 14 days, $7 \mathrm{~S}-\mathrm{R}$ - group starved for 7 days and refed for 21 days, 14 S-R - group starved for 14 days and refed for 21 days, S C - starved control. 
Table 4. Changes in the antioxidant enzymes' activities, oxidative changes in the biomolecules and the changes of the $h s p$ gene expression level produced in the liver of $A$. stellatus during starvation and refeeding when compared to constant feeding.

\begin{tabular}{lllll}
\hline & $7 \mathrm{~S}$ & $7 \mathrm{~S}-\mathrm{R}$ & $14 \mathrm{~S}$ & $14 \mathrm{~S}-\mathrm{R}$ \\
\hline SOD & - & $\uparrow$ & - & $\uparrow$ \\
\hline CAT & - & $\uparrow$ & $\uparrow$ & $\uparrow$ \\
\hline GPx & $\downarrow$ & - & - & - \\
\hline GR & $\downarrow$ & $\uparrow$ & $\uparrow$ \\
\hline GST & - & $\uparrow$ & $\uparrow$ \\
GSH & $\uparrow$ & $\uparrow$ & - & - \\
\hline G6PDH & - & $\uparrow$ & - & $\uparrow$ \\
\hline MDA & $\downarrow$ & - & $\downarrow$ & - \\
\hline PCG & - & - & - & - \\
\hline AOPP & $\downarrow$ & - & $\uparrow$ & $\uparrow$ \\
\hline hsp70 & - & - & $\uparrow$ & $\downarrow$ \\
\hline hsp90a & - & - & $\uparrow$ & - \\
\hline hsp90 & - & - & $\uparrow$ & $\uparrow$ \\
\hline
\end{tabular}

Note: up arrow indicates an increase in the activity or level, down arrow indicates a decrease in the activity or level, and a flat line indicates unchanged activity or level. Semibold font marks the enzymes and molecules with antioxidant roles, while Bold marks the oxidative changes in the biomolecules and stress markers.

A particular observation was that the SGR decrease was inversely correlated to the length of starvation period. This could be explained by the fact that weight loss is reduced over time due to a decline in the metabolic rate in sturgeons (Hung et al., 1997). Starvation also caused a negative effect on SGR of $H$. huso, while refeeding had significantly improved the SGR in the starved fish (Falahatkar et al., 2012).

Low HSI values observed during starvation periods in our study might indicate a depletion of energy stores in the liver of $A$. stellatus juveniles, whereas the increase in HSI values during refeeding might suggest a recovery of the energy deposits. A common response to food deprivation consists of mobilization of nutrient and energy reserves stored in the liver and the skeletal muscles. Consequently, this leads to body and liver weight loss (Navarro \& Gutierrez, 1995), which could explain a decrease in the HSI value observed in our study. Our results are consistent with those suggesting that in a 10week starvation period the liver and viscera of white sturgeon $A$. transmontanus were more susceptible to nutrient mobilization (Hung et al., 1997).

Taken together, all of the morphometric parameters suggest that refed $A$. stellatus juveniles presented compensatory growth, reaching the same weight of the fed control. Due to the fact that SGR, weight gain and the $\mathrm{K}$ value of juveniles from the $7 \mathrm{~S}-\mathrm{R}$ group were similar to those observed for the Fed C group $(P>0.05)$, it can be stated that the 7/21-day starvation/refeeding regime does not affect growth performance and welfare of A. stellatus juveniles.

Our results are consistent with those reported in the literature. Thus, it was demonstrated that starvation led to a decrease in HSI that was proportional to the length of starvation period in A. baerii (Ashouri et al., 2013), and reduced different morphometric parameters in $A n$ guilla anguilla (Caruso et al., 2012), lake sturgeon Acipenser fulvescens (Gillis \& Ballantyne, 1996), D. labrax juveniles
(Gutierrez et al., 1991) and Atlantic cod Gadus morbua (Guderley et al., 2003).

A complete compensatory growth was also demonstrated in $A$. baerii sub-yearlings subjected to different starvation/refeeding regimes (Morshedi et al., 2013). Both, the $A$. sinensis (Liu et al., 2011) and A. persicus juveniles (Yarmohammadi et al., 2013) presented a complete compensatory growth when subjected to refeeding after short-term starvation (maximum one week) and presented only a partial compensation when they were refed after long-term starvation (more than two weeks). Also, $H$. buso presented a partial compensation when starved for 2 or 3 weeks and refed afterwards (Falahatkar et al., 2012).

In contrast to our results, $I$. punctatus fingerlings refed after different starvation periods did not present a catchup growth adequate to compensate for previous weight loss observed during starvation periods (Gaylord et al., 2001).

The 7-day starvation period induced no modification in SOD, CAT and GST activities and even reduced the GPx and GR activities when compared to constant feeding, suggesting that the 7-day starvation period did not induce oxidative stress in the liver of $A$. stellatus. Moreover, the 7-day starvation period decreased the level of lipid peroxidation and protein oxidation as reflected by lower MDA and AOPP levels when compared to the constant feeding regime. The GSH level increased during the 7-day starvation period, indicating an increase of the cellular antioxidant defense capacity.

Refeeding after 7-day starvation period only increased the SOD and CAT activities, the activities of GPx, GR and GST remaining unchanged when compared to the constant feeding regime. Nutrient uptake during refeeding had probably activated the activities of Complex I and Complex III of mitochondrial electron transport chain in the inner mitochondrial membrane, leading to ROS overproduction that determined an intensification of SOD-CAT system activity. However, MDA, AOPP and PCG levels were similar to the control levels, suggesting that lipid peroxidation and protein oxidation processes were not activated by the ROS production during refeeding. Probably, the enhancement of SODCAT system activity efficiently neutralized ROS and as a consequence, the lipids and proteins were protected against the ROS mediated oxidation. The GSH level was still higher than the control level, and this fact, alongside with the unchanged GPx-GR system activity, suggests that lipid peroxides (GPx substrates) were not produced during refeeding. Also, $\mathrm{H}_{2} \mathrm{O}_{2}$ which represents another GPx substrate might have been entirely decomposed by CAT, since CAT activity had significantly increased during refeeding and CAT has a higher Michaelis constant $\left(K_{\mathrm{M}}\right)$ for this substrate when compared to GPx (Kirkman et al., 1987). The inversely correlated levels of CAT and GPx activity were also reported for $A$. naccarii and O. mykiss (Trenzado et al., 2006).

In contrast to the 7-day starvation period, the 14-day starvation period increased the activities of CAT, GR and GST enzymes when compared to constant feeding, suggesting that ROS were produced and the antioxidant systems were activated. As a consequence, these decreased the level of lipid peroxidation and maintained a normal protein oxidation status similar to the control level. The intensification of CAT activity could have also led to an unchanged GPx activity.

In contrast to refeeding after a 7-day starvation period, refeeding after a 14-day starvation period had induced not only the activation of SOD-CAT system, 
but also the activation of the GR and GST enzymes, suggesting that a higher amount of ROS and GST substrates were produced during refeeding after 14-day starvation. However, even though the antioxidant enzymes were activated, the neutralization of ROS was not very effective since protein oxidation took place, as reflected by the increased level of AOPP. Only the lipid peroxidation could be prevented, the MDA level being similar to the control one. Similarly to the cases mentioned above, the raise in CAT activity could generate an unchanged GPx activity.

Furthermore, when comparing the two refeeding regimes, it becomes clear that the 14/21-day starvation/ refeeding regime induced oxidative stress to a greater extent than the 7/21-day starvation/refeeding regime because it induced intensification of the CAT, GPx, GR and GST activities and increased the level of lipid peroxidation and protein oxidation as reflected by higher MDA, PCG and AOPP levels. Thus, the 14/21-day starvation/refeeding regime induced a higher level of ROS that generated lipid peroxidation which can be correlated with the increase in PCG, as well as a raise in AOPP levels, when compared to the 7/21-day starvation/refeeding regime that maintained a low degree of protein oxidation despite ROS production.

Moreover, the 14/21-day starvation/refeeding reduced the concentration of GSH and increased the GPx and GST activities when compared to the 7/21-day starvation/refeeding regime. The fact that the GSH level was inversely proportional to the GPx and GST activities indicates an intensive use of GSH by these enzymes. Therefore, the 14/21-day starvation/refeeding regime determined the mobilization of cellular GSH stocks with the enhancement of antioxidant enzyme activities, so that the oxidative damage to the molecules could be avoided. In contrast, GSH mobilization was not needed in the 7/21-day starvation/refeeding regime, probably due to the low level of oxidative stress induced. In accordance to our results, oxidation of GSH was amplified in $S$. aurata subjected to partial or total food deprivation for 46 days (Pascual et al., 2003).

Previous studies report various results regarding the effects of starvation/refeeding regimes on oxidative stress biomarkers in fish because the species and age of the individuals, the periods of starvation and refeeding, as well as the methods used are highly different. The activities of several antioxidant enzymes (SOD, CAT, GPx or GR) significantly increased in the liver of sexually immature $D$. dentex individuals starved for 5 weeks (Morales et al., 2004), in blood of binni Mesopotamichthys sharpeyi fingerlings subjected to short-term starvation (Najafi et al., 2014), and in partially food deprived gilthead bream Sparus aurata (Pascual et al., 2003). During refeeding all values returned to control levels, suggesting that oxidative damage was reversible. Also, the activities of SOD, CAT, GPx and GR in the liver of brown trout Salmo trutta increased during the 49-day starvation, whereas GST activity decreased, indicating that total or partial food deprivation induced oxidative stress in brown trout (Bayir et al., 2012). Furthermore, an increase in the activities of CAT, GPx and GST was observed in the liver of $G$. morhua during a 12 -week starvation period (Guderley et al., 2003).

On the other hand, no variations in the CAT, SOD and GPx activities were observed in the liver of D. labrax between the starved, refed and control groups (Antonopoulou et al., 2013). In contrast, an enhancement of the total antioxidant blood capacity in $A$. sinensis was reported in the first 19 days of starvation, followed by its reduction (Feng et al., 2011). Also, starvation induced oxidative stress in the liver of $A$. naccarii and $O$. mykiss and the stress level was not removed during subsequent refeeding, a decreasing trend in the enzymatic activities of CAT, SOD, GPx and GR (Furné et al., 2009) being noticed.

An interesting result of our study is the fact that starvation determined a decline in the lipid peroxidation, and refeeding determined a compensatory increase. In contrast to our results, MDA level increased in the liver of $S$. trutta during long-term starvation and food restriction, and this level did not return to the normal one after the refeeding period (Bayir et al., 2012). Also, lipid peroxidation level had increased in the liver of starved $S$. aurata (Pascual et al., 2003), A. naccarii, O. mykiss (Furné et al., 2009), and D. dentex (Morales et al., 2004), as well as in the blood of $M$. sharpeyi (Najafi et al., 2014). Our result could be explained by the fact that the metabolic rate of the starved individuals might have been reduced due to the lack of lipids and carbohydrate intake. Furthermore, endogenous fat deposits dropped in the liver of sturgeons after 2 days of starvation (Furné et al., 2012). Also, acetyl-coenzyme $\mathrm{A}$ is usually used during starvation to generate the ketone bodies which represent fuels for non-liver tissues and therefore it was not involved in the fatty acids biosynthesis. Thus, given the fact that the fat deposits might have been already depleted after 7 and 14 days of starvation, $\beta$-oxidation could have been diminished and as a consequence, the level of ROS was reduced leading to a decrease in lipid peroxidation. This observation is in accordance with a previous study demonstrating that a caloric restriction diet led to a reduced tissue oxidation state in turbot Scophthalmus maximus (Abele et al., 2007). The intake of exogenous lipids during refeeding activated the $\beta$-oxidation metabolic pathway. As a consequence, the level of acetyl-coenzyme A increased, the rate of Krebs cycle was enhanced and important quantities of $\mathrm{NADH}$ and $\mathrm{FADH}_{2}$ donated electrons to the mitochondrial electron transport chain. Due to this, the physiological ROS level was probably raised, increasing the level of lipid peroxidation during refeeding. However, the refed juveniles presented a lipid peroxidation level similar to that of the constantly fed juveniles, possibly due to the enhancement of the CATSOD enzymatic system observed during both of the starvation/refeeding regimes, and also due to the mobilization of GSH stocks during the 14/21-day starvation refeeding regime.

The profile of G6PDH activity indicates that the pentose phosphate shunt was not affected by starvation and was enhanced during refeeding. The activity of G6PDH is usually decreased during starvation because glycolysis is impaired due to the lack of glucose and because glucose-6-phosphate, an intermediary of glycolysis, is used to a lower extent in the oxidative branch of the pentose phosphate shunt. However, G6PDH activity during both, the 7-day and 14-day starvation periods, was similar to the one observed during constant feeding regime, suggesting that gluconeogenesis was activated in order to sustain the plasma glucose level for the other critical tissues. As a consequence, production of glucose through gluconeogenesis had maintained an active pentose phosphate shunt and thus, the G6PDH activity was unaffected by glucose deprivation. Further on, this enzymatic activity increased during refeeding, probably when glucose uptake from food had occurred, leading to an increased concentration of glucose-6-phosphate; as a result, G6P$\mathrm{DH}$ activity had increased and the oxidative branch of pentose phosphate shunt was intensified, leading to an 
enhanced generation of NADPH. GR had probably used NADPH as a co-factor for regeneration of GSH from GSSG. Thus, refeeding allowed an increase in the GR specific activity when compared to starvation due to input of metabolic fuels in the juveniles' liver (observed for the $7 \mathrm{~S}-\mathrm{R}$ group when compared to the $7 \mathrm{~S}$ group).

In contrast to our results, an inhibition of G6PDH activity was reported in the liver of starved $D$. dentex (Morales et al., 2004) and S. trutta (Bayir et al., 2012).

Regarding the stress response mechanisms, the 7/21day starvation/refeeding regime did not induce significant changes in the hsp gene expression level, indicating that a cellular stress response has not been driven in the liver of $A$. stellatus juveniles. In contrast, the 14/21-day starvation/refeeding regime strongly modified the level of hsp gene expression, suggesting that a major cellular stress response has been induced. The up-regulation of hsp gene expression encountered during the 14-day starvation period might be an indicator of a high stress level (Iwama et al., 1998), but it is also considered to be a cellular defense method against stress inducer factors (Sørensen et al., 2003). In addition, it is considered as a way to cope with the stress, leading to adaptation and raised survival chances (Basu et al., 2002).

The Hsp70 protein has an anti-apoptotic effect, since it binds the Apaf-1 apoptotic factor, inhibiting the assembly of the Apaf-1-caspase-9-cytochrome c complex (Ravagnan et al., 2001). Therefore, strong down-regulation of the $h s p 70$ gene expression might lead to a pronounced apoptosis and might generate deleterious effects in the liver functions. Therefore, 14/21-day starvation/ refeeding regime that induced a down-regulation of bsp70 gene expression might threaten the functions of the liver.

Previously, it was found that food deprivation did not influence the level of transcription of $h s p 30, \quad h s p 70$ and hsp90 in gills of Salmo salar juveniles at all (Zarate \& Bradley, 2003).

Overall, our data suggest that ROS were induced only after 14 days of starvation, leading to enhanced activity of antioxidant enzymes such as: CAT, GR and GST in the liver of $A$. stellatus. The stress response was also triggered at 14 days of starvation, increasing all tested hsp genes' expression. However, ROS were entirely neutralized by the antioxidant enzymes and even more, since the lipid peroxidation decreased and proteins were spared from oxidation when compared to the control level observed during constant feeding. Further on, refeeding after starvation induced ROS to a greater extent than starvation and gradually activated almost all antioxidant enzymes. The lipid peroxidation increased, but did not surpass the control level, while protein oxidation and the down-regulation of hsp gene expression occurred when juveniles were refed after 14-day starvation. $A$. stellatus juveniles might have responded to starvation by reducing the basal metabolic rate in order to adapt to the lack of food, while the metabolic rate might have been enhanced during refeeding in order to compensate the reduction that had occurred during starvation. Fish adopt the catabolic energy conservation strategy in response to food deprivation in order to minimize the tissue energy loss (Navarro \& Gutierrez, 1995). Therefore, the absence of exogenous glucose and fatty acids during food deprivation could have led to a lower catabolism and, as a consequence, to a diminished production of ROS supplied by physiological oxidation reactions. As a consequence, lipid peroxidation level was reduced and the protein oxidation status was unaffected or reduced during starvation periods. The intake of glucose and fat- ty acids during refeeding might have determined a restart in all of the metabolic pathways and an increase in ROS production, thus leading to a greater enhancement of the antioxidant enzymes' activities.

According to Guderley (Guderley, 2003), starvation determines a mobilization of energy reserves that affects the cellular components, rendering them prone to ROS. Therefore, the cells that could suffer oxidative damage enhance their antioxidant enzymatic system activities during starvation as a measure of prevention. Moreover, according to Trenzado (Trenzado, 2006), sturgeon liver synthesizes lipids in high amounts under physiological conditions, these being rich in PUFA that are prone to peroxidation. Therefore, it is stated that sturgeons possess a natural and effective antioxidant defense, increasing the level of antioxidants in order to prevent the peroxidation of fat deposits in the liver.

An interesting observation regarding our data is that the level of oxidative stress biomarkers and of gene expression of all heat shock biomarkers was not statistically different between the fed and starved controls. These findings could be interpreted as an adaptation of the juveniles to long-term starvation. The ability to cope with starvation is well documented in the wild $A$. stellatus mature individuals. These are capable to endure months without feeding during their migration and reproductive seasons due to the energy stores they previously accumulate (Bemis \& Kynard, 1997). Also, fish alternate feeding with starvation periods because of seasonal variations in temperature and food availability (Madrid et al., 2001). This observation has not been made before for juveniles that need energy resources for growth and development, and that are supposed to present a continuous feeding behavior. However, wild juveniles might experience short periods of food deprivation because of the food availability, so they might not eat on a daily basis. Therefore, might short-term starvation periods be included in the feeding regime of juveniles raised in fish farms in order to provide them with conditions similar to those found in natural habitats and to reduce the cost in aquaculture production? As was shown in this study, starvation/refeeding regimes may influence growth performance, and trigger a stress response as well as induce oxidative stress in comparison to the constant feeding regime in the liver of $A$. stellatus juveniles. However, the juveniles raised in aquaculture conditions proved to be able to adapt to a starvation/refeeding regime. Only the 7/21-day starvation/refeeding regime was properly tolerated by $A$. stellatus juveniles in comparison to 14/21-day starvation/refeeding because: a) the juveniles presented a complete compensatory growth, reaching almost the same weight and HSI values as the constantly fed ones; b) the regime enhanced the antioxidant defense mechanisms and, as a consequence, the juveniles presented the capacity to counteract oxidative stress by neutralizing ROS; c) the regime did not trigger a cellular stress response. As a consequence, if applied in aquaculture, this regime could lower the cost of raising juveniles without affecting their growth performance, welfare and health status.

In contrast, the 14/21-day starvation/refeeding induced a partial compensatory growth and induced oxidative stress that could not be totally counteracted even though the antioxidant enzymatic activities were enhanced. This regime had strongly affected the hsp gene expression, triggering a cellular stress response.

This study is the first one to assess the adaptability of A. stellatus juveniles to different starvation/refeeding regimes by evaluating growth performance indices, oxida- 
tive stress markers and the cellular stress response. The present study is a preliminary one; it must be extended further with similar analyses of other organs. Also, the growth performance and stress defense mechanisms must be evaluated in juveniles subjected to several cycles of starvation/refeeding in order to determine if $A$. stellatus can adapt to this type of regime in the long-term.

In conclusion, $A$. stellatus juveniles possess the ability to adapt to an alternative feeding regime consisting of 7 days of starvation, followed by 21 days of refeeding. This regime was well tolerated by the juveniles and did not affect their growth performance and welfare, representing a promising method to optimize the feeding practice in aquaculture.

\section{REFERENCES}

Abele D, Roecken D, Graeve M, Buck BH (2007) Body growth, mitochondrial enzymatic capacities and aspects of the antioxidant system and redox balance under calorie restriction in young turbot (Scopbthalmus maximus, L.). Aquac Res 38: 467-477. https://doi. org/10.1111/j.1365-2109.2007.01682.x

Altschul SF, Gish W, Miller W, Myers EW, Lipman DJ (1990) Basic local alignment search tool. J Mol Biol 215: 403-410. https://doi. org/10.1016/S00222836(05)80360-2

Antonopoulou E, Kentepozidou E, Feidantsis K, Roufidou C, Despoti S, Chatzifotis S (2013) Starvation and refeeding affect Hsp expression, MAPK activation and antioxidant enzymes activity of European sea bass (Dicentrarcbus labrax). Comp Biochem Physiol (A) 165: 79-88. https://doi.org/10.1016/j.cbpa.2013.02.019

Ashouri G, Yavari V, Bahmani M, Yazdani MA, Kazemi R, Morshedi V, Fatollahi M (2013) The effect of short -term starvation on some physsiological and morphopogical parameters in juvenile Siberian sturgeon Acipenser baerii (Actinopterygii Acipenseriformes Acipenseridare). Acta Ichthyol Piscat 43: 145-150. https://doi.org/10.3750/ AIP2013.43.2.07

Bacalbașa-Dobrovici N (1997) Endangered migratory sturgeons of the lower Danube River and its delta. In Sturgeon biodiversity and conservation. Birstein VJ, Waldman JR, Bemis WE eds, pp 201-207. Kluwer Academic/Plenum Publishers. https://doi.org/10.1007/0-30646854-9

Bansal M, Kaushal N (2014) Oxidative stress mechanisms and their modulation. 1st edn. Springer. https://doi.org/10.1007/978-81-322-2032-9

Basu N, Todgham AE, Ackerman PA, Bibeau MR, Nakano K, Schulte PM, Iwama GK (2002) Heat shock, protein genes and their functional significance in fish. Gene 295: 173-183. https://doi.org/10.1016/S03781119(02)00687-X

Bayir A, Sirkecioglu A, Bayir M, Haliloglu HI, Kocaman EM, Aras NM (2012) Metabolic responses to prolonged starvation, food restriction and refeeding in the brown trout, Salmo trutta: oxidative stress and antioxidant defenses. Comp Biochem Physiol (B) 159: 191-196. https://doi. org/10.1016/i.cbpb.2011.04.008

Beers RF, Sizer IW (1952) A spectrophotometric method for measuring the breakdown of hydrogen peroxide by catalase. J Biol Chem 195: $133-140$

Bemis W, Kynard B (1997) Sturgeon rivers: an introduction to acipenseriform biogeography and life history. In Sturgeon biodiversity and conservation. Birstein VJ, Waldman JR, Bemis WE eds, pp 167-183. Kluwer Academic/Plenum Publishers. https://doi.org/10.1007/0306-46854-9

Beutler E (1984) Red cell metabolism: A manual of biochemical methods. 3rd edn. Grune and Stratton.

Bugeon J, Lefèvre F, Fauconneau B (2004) Correlated changes in skeletal muscle connective tissue and flesh texture during starvation and refeeding in brown trout (Salmo trutta) reared in seawater. I Sci Food Agri 84: 1433-1441. https://doi.org/10.1002/jsfa.1837

Cadenas E, Kelvin JAD (2000) Mitochondrial free radical generation, oxidative stress, and aging. Free Radic Biol Med 29: 222-230. https:// doi.org/10.1016/S0891-5849(00)00317-8

Caruso G, Maricchiolo G, Micale V, Genovese L, Caruso R, Denaro MG (2010) Physiological responses to starvation in the European eel (Anguilla anguilla): effects on haematological, biochemical, nonspecific immune parameters and skin structures. Fish Physiol Biochem 36: 71-83. https://doi.org/10.1016/j.marenvres.2012.07.003

Caruso G, Denaro MG, Caruso R, Genovese L, Mancari F, Maricchiolo G. 2012. Short fasting and refeeding in red porgy (Pagrus pagrus, Linnaeus 1758): response of some haematological, biochemical and non specific immune parameters. Mar Environ Res 81: 18-25. https://doi.org/10.1007/s10695-008-9290-6

De Pedro N, Delgado MJ, Gancedo B, Alonso-Bedate M (2003) Changes in glucose, glycogen, thyroid activity and hypothalamic cat- echolamines in tench by starvation and refeeding. J Comp Physiol (B) 173: 475-481. https://doi.org/10.1007/s00360-003-0355-7

del Rio D, Pellegrini N, Colombi B, Bianchi M, Serafini M, Torta F, Tegoni SM, Musci M, Brighenti F (2003) Rapid fluorimetric method to detect total plasma malondialdehyde with mild derivatization conditions. Clin Chem 49: 690-692. https://doi.org/10.1373/49.4.690

Falahatkar B (2012) The metabolic effects of feeding and fasting in beluga Huso huso. Mar Environ Res 82: 69-75. https://doi. org/10.1016/j.marenvres.2012.09.003

Feng G, Shi X, Huang X, Zhuang P (2011) Oxidative stress and antioxidant defenses after long-term fasting in blood of chinese sturgeon (Acipenser sinensis). Procedia Environ Sci 8: 469-475. https://doi. org/10.1016/j.proenv.2011.10.074

Fields R, Dixon HBF (1971) Micro method for determination of reactive carbonyl groups in proteins and peptides, using 2,4-dinitrophenylhydrazine. Biochem J 121: 587-589. https://doi.org/10.1042/ bj1210587

Furné M, Garcia-Gallego M, Hidalgo MC, Morales AE, Domezain A, Domezain J, Sanz A (2009) Oxidative stress parameters during starvation and refeeding periods in Adriatic sturgeon (Acipenser naccarii) and rainbow trout (Oncorbynchus mykiss). Aquac Nutr 15: 587-595. https://doi.org/10.1111/j.1365-2095.2008.00626.x

Furné M, Morales AE, Trenzado CE, Garcia-Gallego M, Hidalgo MC, Domezain A, Sanz Rus A (2012) The metabolic effects of prolonged starvation and refeeding in sturgeon and rainbow trout. $I$ Comp Physiol (B) 182: 63-76. https://doi.org/10.1007/s00360-0110596-9

Gamperl KA, Farrell AP (2004) Cardiac plasticity in fishes: environmental influences and intraspecific differences. I Exp Biol 207: 2539-2550. https:// doi.org/10.1242/jeb.01057

Gaylord TG, MacKenzie DS, Gatlin DM (2001) Growth performance, body composition and plasma thyroid hormone status of channel catfish (Ictalurus punctatus) in response to short-term feed deprivation and refeeding. Fish Physiol Biochem 24: 73-79. https://doi. org/10.1023/A:1011199518135

Gillis TE, Ballantyne JS (1996) The effects of starvation on plasma free amino acid and glucose concentrations in lake sturgeon. J Fish Biol 49: 1306-1316. https://doi.org/0022-1112/96/121306

Goldberg DM, Spooner RJ (1986) Glutathione reductase. In Methods of ensymatic analysis. Bergmeyer HU ed, pp 258-265. Verlag Chemie.

Guderley H, Lapointe D, Bedard M, Dutil JD (2003) Metabolic priorities during starvation: enzyme sparing in liver and white muscle of Atlantic cod, Gadus morbua L. Comp Biochem Physiol (A) 135: 347-356. https:// doi.org/10.1016/S1095-6433(03)00089-8

Guérod F (2010) Lipid peroxidation originating $\alpha, \beta$-unsaturated aldehydes and their metabolites as biomarkers. In Biomarkers for antioxidant defense and oxidative damage: principles and practical applications. Aldini G, Yeum KJ, Niki E, Russell RM eds, pp 117-136. Wiley-Blackwell

Gunther J, Galvez-Hidalgo N, Ulloa-Rojas J, Coppoolse J, Verreth JAJ (1992) The effect of feeding level on growth and survival of jaguar guapote (Cicblasoma managuense) larval fed Artemia nauplii. Aquaculture 107: 347-358. https://doi.org/10.1016/0044-8486(92)90082-V

Gutierrez J, Perez J, Navarro I, Zanuy S, Carillo M (1991) Changes in plasma glucagon and insulin associated with fasting in sea bass (Dicentrarchus labrax). Fish Physiol Biochem 9: 107-112. https://doi. org/10.1007/BF02265126

Habig WH, Pabst MJ, Jakoby WB (1974) Glutathione S-transferases. The first enzymatic step in mercapturic acid formation. J Biol Chem 249: $7130-7139$

Hensel K, Holcík J (1997) Past and current status of sturgeons in the upper and middle Danube River. In Sturgeon biodiversity and conservation. Birstein VJ, Waldman JR, Bemis WE eds, pp 185-200. Kluwer Academic/Plenum Publishers. https://doi.org/10.1007/0-30646854-9

Heydari AR, Conrad CC, Richardson A (1995) Expression of Heat shock genes in hepatocytes is affected by age and food restriction in rats. I Nutr 125: 410-418

Hornick JL, Van Eenaeme C, Gérard O, Dufrasne I, Istasse L (2000) Mechanisms of reduced and compensatory growth. Domest Anim Endocrin 19: 121-132. https://doi.org/10.1016/S0739-7240(00)00072-2

Hung SSO, Liu W, Li H, Storebakken T, Cui Y (1997) Effect of starvation on some morphological and biochemical parameters in white sturgeon, Acipenser transmontanus. Aquaculture 151: 357-363. https:// doi.org/10.1016/S0044-8486(96)01506-2

Iwama GK, Thomas PT, Forsyth RB, Vijayan MM (1998) Heat shock protein expression in fish. Rev Fish Biol Fish 8: 35-56. https://doi. org/10.1023/A:1008812500650

Kirkman HN, Galiano S, Gaetani GF (1987) The function of catalasebound NADPH. J Biol Chem 262: 660-666

Liu W, Wei QW, Wen H, Jiang M, Wu F, Shi Y (2011) Compensatory growth in juvenile Chinese sturgeon (Acipenser sinensis): effects of starvation and subsequent feeding on growth and body composition. J Appl Icbtbyol 27: 749-754. https://doi.org/10.1111/j.14390426.2011.01723.x 
Livak KJ, Schmittgen TD (2001) Analysis of relative gene expression data using Real-Time Quantitative PCR and the 2-DDCT Method. Methods 25: 402-408. https://doi.org/10.1006/meth.2001.1262

Lohr GW, Waller HD (1974) Glucose-6-phosphate dehydrogenase. In Methods of ensymatic analysis. Bergmeyer HU ed, pp 744-751. Academic Press

Lowry OH, Rosebrough NJ, Farr AL, Randall RJ (1951) Protein measurement with Folin phenol reagent. I Biol Chem 193: 265-275

Madrid JA, Boujard T, Sanchez-Vazquez FJ (2001) Feeding rhythms. In Food intake in fish. Houlihan D, Boujard T, Jobling M eds, pp 189-215. Blackwell Science Ltd. https://doi. org/10.1002/9780470999516.ch8

Masoro EJ (1992) Retardation of aging processes by food restriction: an experimental tool. Am J Clin Nutr 55: 1250-1252

McCue MD (2010) Starvation physiology: reviewing the different strategies animals use to survive a common challenge. Comp Biochem Physiol (A) 156: 1-18. https://doi.org/10.1016/j.cbpa.2010.01.002

Meister A (1989) On the biochemistry of glutathione. In Molecular perspectives and clinical implications. Glutathione centennial. Taniguchi N, Higashi T, Sakamoto S, Meyster A eds, pp 3-21. Academic Press

Miyamoto S, Arai H, Terao J (2010) Enzymatic antioxidant defenses. In Biomarkers for antioxidant defense and oxidative damage: principles and practical applications. Aldini G, Yeum KJ, Niki E, Russell RM eds, pp 21-34. Wiley-Blackwell

Morales AE, Perez-Jimenez A, Hidaloo MC, Abellan E, Cardenete G (2004) Oxidative stress and antioxidant defenses after prolonged starvation in Dentex dentex liver. Comp Biochem Physiol (C) 139: 153 161. https://doi.org/10.1016/j.cca.2004.10.008

Morshedi V, Kochanian P, Bahmani M, Yazdani MA, Pourali HR Ashouri G, Pasha-Zanoosi H, Azodi M (2013) Compensatory growth in sub-yearling Siberian sturgeon, Acipenser baerii Brandt, 1869: effects of starvation and refeeding on growth, feed utilization and body composition. J Appl Ichthyol 29: 978-983. https://doi. org/10.1111/jai.12257

Mueller S, Riedel HD, Stemmel W (1997) Direct evidence for catalase as the predominant $\mathrm{H}_{2} \mathrm{O}_{2}$ removing enzyme in human erythrocytes. Blood 90: 4973-4978

Najafi A, Salati AP, Yavari V, Asadi F (2014) Effects of short-term starvation and refeeding on antioxidant defense status in Mesopotamichthys sharpeyi (Günther, 1874) fingerlings. Intl J Aquat Biol 2: $246-252$

Navarro I, Gutierrez J (1995) Fasting and starvation. In Biochemistr and molecular biology of fishes. Hochachka PW, Mommsen TP eds, pp 393-434. Elsevier.

Paoletti F, Aldinucci D, Mocali A, Caparrini A (1986) A sensitive spectrophotometric method for the determination of superoxide dismutase activity in tissue extracts. Anal Biochem 154: 536-541

Pascual P, Pedrajas JR, Toribio F, Lopez-Barea J, Peinado J (2003) Effect of food deprivation on oxidative stress biomarkers in fish (Sparus aurata). Chem Biol Interact 145: 191-199. https://doi.org/10.1016/ S0009-2797(03)00002-4

Pérez-Jiménez A, Guedes MJ, Morales AE, Oliva-Teles A (2007) Metabolic responses to short starvation and refeeding in Dicentrarchus labrax. Effect of dietary composition. Aquaculture 265: 325-335. https://doi.org/10.1016/j.aquaculture.2007.01.021

Pérez-Jiménez A, Cardenete G, Hidalgo MC, Garcia-Alcazar A, Abellan E, Morales AE (2012) Metabolic adjustments of Dentex dentex to prolonged starvation and refeeding. Fish Physiol Biochem 38: 11451157. https://doi.org/10.1007/s10695-011-9600-2

Ravagnan L, Gurbuxani S, Susin SA, Maisse C, Daugas E, Zamzami N, Mak T, Jäättelä M, Penninger JM, Garrido C, Kroemer G (2001) Heat-shock protein 70 antagonizes apoptosis-inducing factor. Nat Cell Biol 3: 839-843. https://doi.org/10.1038/ncb0901-839

Requena JR, Chao CC, Levine RL, Stadtman ER (2001) Glutamic and aminoadipic semialdehydes are the main carbonyl products of metal - catalyzed oxidation of proteins. Proc Natl Acad Sci US A 98: 68 -74. https://doi.org/10.1073/pnas.98.1.69

Shepherd CJ, Bromage NR (1988) Intensive Fish Farming. 1st edn. Blackwell Scientific Publications.

Sørensen JG, Kristensen TN, Loeschcke V (2003) The evolutionary and ecological role of heat shock proteins. Ecol Lett 6: 1025-1037. https://doi.org/10.1046/j.1461-0248.2003.00528.x

Thomas EL (1979) Myeloperoxidase, hydrogen peroxide, chloride antimicrobial system: nitrogen-chlorine derivatives of bacterial components in bactericidal action against Escherichia coli. Infect Immun 23: 522-531

Thornalley PJ, Rabbani N (2010) Oxidative modifications of proteins: an overview. In Biomarkers for antioxidant defense and oxidative damage: principles and practical applications. Aldini G, Yeum KJ, Niki E, Russell RM eds, pp 137-156. Wiley-Blackwell.

Trenzado C, Hidalgo MC, García-Gallego M, Morales AE, Furné M, Domezain A, Domezain J, Sanz A (2006) Antioxidant enzymes and lipid peroxidation in sturgeon Acipenser naccarii and trout Oncorbynchus mykiss. A comparative study. Aquaculture 254: 758-767. https://doi. org/10.1016/j.aquaculture.2005.11.020

Weatherly AH, Gill HS (1987) The biology of fish growth. 1st edn. Academic Press

Weindruch R, Keenan KP, Carney JM, Fernandez G, Feuers RJ, Floyd RA, Halter JB, Ramsey JJ, Richardson A, Roth GS, Spindler SR (2001) Caloric restriction mimetics: metabolic interventions. J Gerontol Biol Sci (A) 56: 20-33

Witko V, Nguyen AT, Descamps-Latscha B (1992) Microtiter plate assay for phagocyte-derived taurine-chloramines. J Clin Lab Anal 6: $47-53$

Witko-Sarsat V, Gausson V, Descamps-Latscha B (2003) Are advanced oxidation protein products potential uremic toxins? Kidney Int 63: S11-S14.

Yarmohammadi M, Shabani A, Pourkazemi M, Soltanloo H, Imanpour MR, Ramezanpour S, Smith-Keune C, Jerry DR (2013) Effects of starvation and refeeding on compensatory growth performance, plasma metabolites and IGF-I gene expression of Persian sturgeon (Acipenser persicus, Borodin 1897). Iran J Fish Sci 12: 465-483

Zarate J, Bradley TM (2003) Heat shock proteins are not sensitive indicators of hatchery stress in salmon. Aquaculture 223: 175-187. https://doi.org/10.1016/S0044-8486(03)00160-1 